\title{
PROVIDING GUIDELINE PRINCIPLES: BOTANY AND ECOLOGY WITHIN THE STATE FOREST SERVICE OF NEW ZEALAND DURING THE 1920s
}

ANTON SVEDING

\section{Abstract}

This article examines the application of the sciences of botany and ecology by New Zealand's State Forest Service (SFS) during the first half of the 1920s. Previous research concerning the SFS has primarily focused on its Director of Forestry, Leon Maclntosh Ellis, and the shift from a forestry practice based on the ideas of sustainedyield management of indigenous trees to exotic afforestation. By studying the use and attributed value of botany and ecology, or 'ecological and silvicultural research' as the service categorised it, a wider knowledge can be gained on why sustained-yield management was abandoned for exotic afforestation, in addition to exploring changes in the relationship between state and science in New Zealand during the first half of the 1920s. In addition, by studying the Swedish Australasian Botanical Expedition, led by the Swedish lichenologist G. Einar Du Rietz, touring New Zealand for seven months in 1926-27, this article is able to explore the influence of non-British expertise during the 1920 s in issues related to forestry management.

Keywords: botany, lichenology, forestry, ecology, science production, history, New Zealand

\section{Science and state in New Zealand in the early twentieth century}

During the late nineteenth century, science gradually became more professionalised throughout the British-influenced world due to a number of factors, among them an 'increasing number of jobs requiring scientific knowledge and skills' as well as 'demands for greater recognition through more and better paid positions, 
money for research, and more respect for expert knowledge'. ${ }^{1}$ In the case of New Zealand, the government funded numerous agencies employing scientific experts, particularly in geology, agriculture and natural history. ${ }^{2}$ A majority of the research efforts conducted at these agencies dealt with issues related to primary industries. For example, the Department of Agriculture (established in 1892) 'tried to address problems of declining productivity, farm failure and reversion of pasture land to native scrub and bush by turning to science for help. ${ }^{3}$ In 1926, the New Zealand Government, once again influenced by Britain, established the Department of Scientific and Industrial Research (DSIR), Britain having formed a DSIR 10 years earlier. The purpose of New Zealand's DSIR was to bring together the government's scientific institutions as well as to create new ones, by seeking 'a more effective and efficient means of matching the resources of science to the needs of economic development'. ${ }^{4}$ It became an umbrella for science, with divisions researching geology, climate and native flora and fauna, among others, providing scientific advice to commerce and industry. Before long, according to the historian of science Ross Galbreath, the DSIR became 'synonymous with science in New Zealand'.5 However, before the founding of the DSIR much of the scientific research in the country was scattered across governmental agencies, the State Forest Service (SFS) being one of them. The aim of this article is to bring attention to scientific research carried out by the SFS during the first half of the 1920s, before the establishment of the DSIR. More specifically, this article studies what value the service ascribed botany and ecology and why the two sciences were important for forestry in New Zealand. A second aim of the article is to bring attention to how the service came to hire experts temporarily, both domestic and foreign, exemplified by the Swedish Australasian Botanical Expedition, which highlighted the hiring of non-British expertise during the 1920 s. $^{6}$

\footnotetext{
1 Ruth Barton, "Men of Science”: Language, Identity and Professionalization in the Mid-Victorian Scientific Community', History of Science 41, no. 1 (March 2003): 77, doi.org/10.1177/007327530304100103.

2 Rebecca Priestley, 'A Survey of the History of Science in New Zealand, 1769-1992', History Compass 8, no. 6 (June 2010): 481, doi.org/10.1111/j.1478-0542.2010.00684.x.

3 Tom Brooking and Paul Star, 'Remaking the Grasslands: the 1920s and 1930s', in Seeds of Empire: The Environmental Transformation of New Zealand, ed. Tom Brooking and Eric Pawson (London: I. B. Tauris, 2011), 182. 4 Ross Galbreath, DSIR: Making Science Work for New Zealand. The History of the Department of Scientific and Industrial research, 1926-1992 (Wellington: Victoria University Press in association with the Historical Branch Department of Internal Affairs, 1998), 9.

5 ibid.

6 Previous research on the topichas particularly studied the hiring of German expertise in forestry matters, especially in India; see, for example, James Beattie, Empire and Environmental Anxiety: Health, Science, Art, Conservation in South Asia and Australasia (Basingstoke: Palgrave Macmillan, 2011), Chapter 6, doi.org/10.1057/9780230309067; Ulrike Kirchberger, 'German scientists in the Indian Forest Service: A German contribution to the Raj?' Journal of Imperial and Commonwealth History 29, no. 2 (2001): 1-26, doi.org/10.1080/03086530108583117.
} 


\section{The State Forest Service and ecology}

In 1919, Leon MacIntosh Ellis, a young and energetic Canadian forester, was appointed Director of Forests over New Zealand's recently created Forestry Department, shortly afterwards renamed the State Forest Service. As Director of Forests, Ellis was responsible for preventing a timber famine striking in New Zealand. It was a tremendous task; a report commissioned a few years prior to his employment suggested that the Dominion would have depleted its source of merchantable timber by 1943. Ellis acted quickly, and only a year after his appointment he presented a proposal for a new forest policy, which he believed would ensure a sustainable supply of timber. Despite financial problems, Ellis managed to convince the government to support a majority of his suggested measures, among them the establishment of a bureau of forest research. ${ }^{7}$ In his proposal, Ellis argued a forest research centre is absolutely necessary if we are to make any advance in the solution of the forest problems of New Zealand. This cannot be urged too strongly'. As his writing in cursive shows, the formation of a bureau was essential to Ellis. Simultaneously, Ellis was concerned with the absence of systematic observations and studies of the indigenous forests, causing him to write:

No investigations have been made as to the fundamental requirements of forestry as applied to the great indigenous forest. To-day we must start from zero and gradually build up knowledge upon which our programme may be based. In forestry we are dealing with nature and time, therefore the study of nature's modus operandi must be begun at once, so that by the time the State forests are demarcated it will be definitely possible to prescribe the finer details necessary for their management. ${ }^{9}$

Ellis found the lack of research problematic for two reasons. First, it made it difficult to conduct forestry adapted to the particular conditions of the indigenous forests of New Zealand. Though there had in fact been several surveys of the native forests, by botanists and foresters alike, they were disregarded, or overlooked, by Ellis. ${ }^{10}$ Second, and more importantly, investigating the indigenous forests would require time. With a timber famine looming on the horizon, time was a precious resource. Unfortunately, because of the lack of research, Ellis first had to spend time investigating the indigenous forests prior to managing them. ${ }^{11}$ Previous historical research into the work of Ellis and the SFS during the 1920s has focused on the implementation

\footnotetext{
Roche, History of Forestry, 192.

Appendices to the Journals of the House of Representatives [hereafter AJHR], C3A, 1920, 14.

AJHR, C3A, 1920, 14.

10 See, for example, Joseph Dalton Hooker, Handbook of the New Zealand flora: A systematic description of New Zealand and the Chatham, Kermadec's Lord Auckland's, Campbell's and Macquarrie's Islands (London: Reeve, 1867); Thomas Kirk, The forest flora of New Zealand (Wellington: Government Printer, 1989); Leonard Cockayne, 'Report on a botanical survey of the Waipoua Forest', AJHR, C14, 1908; David Hutchins, New Zealand forestry: Part 1, Kauri forests and forests of the north and forest management (Wellington: Department of Forestry, 1919).

11 AJHR, C3A, 1920, 14.
} 
and abandonment of sustained-yield management for exotic afforestation, and on the institution itself. ${ }^{12}$ While these studies provide a thorough picture of the SFS and forestry policies, they have paid less attention to the relation between the science of ecology and of forestry based on sustained-yield management. ${ }^{13}$ As this article will show, ecology, and botany in particular, constituted significant scientific cornerstones of the research conducted by the SFS during the 1920s. While Ellis convinced the government of the need for a research bureau, the possibilities of undertaking large-scale research projects were hampered by a shortage of personnel. For example, in 1923 the service employed 95 people in total. ${ }^{14}$ Because of its small size, and financial difficulties prohibiting the possibility of employing research personnel permanently, it became necessary to hire expertise temporarily. During the early years of the 1920s, the SFS employed Leonard Cockayne, Charles Ethelbert Foweraker, William Roy McGregor and Charles Chilton, all skilful researchers in either botany or zoology, to either conduct or supervise studies on the indigenous forests. In the annual reports of the SFS, their research was categorised under various headings, such as silvical or silvicultural research, 'ecological and silvical research' and 'forest ecology', to mention a few, during Ellis' tenure as director of forests. ${ }^{15}$ The investigations undertaken by these men dealt with various kinds of forests and aspects. The aim and progress of these studies was summarised in the annual reports, providing an insight to why Ellis considered them useful. A good example is how Ellis portrayed McGregor's research on 'the life-history of the kauri' and the ecology of the northern forests. In the first annual report, Ellis writes how the investigation 'is of immense value to the programme of forest-management'. Ellis also underlined how McGregor had discovered 'certain practical conclusions of general nature', among them how the natural regeneration of kauri and other indigenous trees was 'dependent on the shade of a natural shelter wood'. As Ellis hoped to conduct a forestry based on the principles of sustained-yield management of the native forests, general laws on its regeneration were essential. The next reports portrayed McGregor's work in very similar words, consistently describing how he made 'substantial progress' with his research, until $1924 .{ }^{16}$ In the annual report for that year, Ellis's previously optimistic and hopeful summarisation has changed; he describes it in only two sentences: '[t]his study was continued during the year by

12 See, for example, Michael Roche, '(Re)Interpreting Exotic Plantation Forestry in New Zealand', International Review of Environmental History 1 (August 2015): 147-72, doi.org/10.22459/IREH.01.2015.06; Michael Roche, 'An interventionist state: "wise use" forestry and soil conservation', in Making a New Land: Environmental Histories of New Zealand, ed. Eric Pawson and Tom Brooking (Dunedin: Otago University Press, 2013), 209-25; Michael Roche, History of Forestry (Wellington: New Zealand Forestry Corporation in association with GP Books, 1990): see Chapter 4 in particular for the origin of the State Forest Service and the work of Leonard MacIntosh Ellis.

13 Roche, History of Forestry, 192-9.

14 AJHR, C3, 1923, 5.

15 In the reports for 1921, 1922, 1924 and 1925, their research is categorised only as silvical or silvicultural, and in the report for 1926 as 'ecological research' and silvicultural investigations. Lastly, in 1927, it is referred to as 'forest ecology': AJHR, C3, 1921, 9; AJHR, C3, 1922, 11ff; AJHR, C3, 1923, 12; AJHR, C3, 1924, 11; AJHR, C3, 1925, 18; AJHR, C3, 1926, 19ff; AJHR, C3, 1927, 20.

16 AJHR, 1921. 
Mr. W. R. McGregor ... Definitive recommendations as to the silvical needs and minimum silvicultural requirements of these forest types will be finalized during this year'. ${ }^{17}$ However, McGregor failed to complete his investigation and it featured in the next year's report as well. Much like the previous year, Ellis mentioned McGregor only briefly, noting how the research would be completed within a year; he did not state why the report was delayed..$^{18}$ In his research, the historical geographer Michael Roche shows how a growing disagreement between the SFS and McGregor concerning material support, but also financial issues, resulted in a rift between the two; the report was never finalised. ${ }^{19}$ Later, during the mid-1940s, McGregor would argue for the conservation of Waipoua forest, one of those he had surveyed 20 years earlier. While Ellis' annual reports may not mention conflicts and disagreements, they do provide a great insight into how he portrayed the need for ecological research. Simultaneously as McGregor investigated the kauri forests of the north, Cockayne and Foweraker researched beech forests and the Westland rain forest respectively. ${ }^{20}$ Cockayne's research, Ellis wrote, would result in observations concerning regeneration and the rate of growth of the beech forests, which would provide fundamental knowledge for 'any method of silivculture'. ${ }^{21}$ Meanwhile, Ellis described Foweraker's investigation into the ecology and regeneration of taxad rainforests in the Westlands as an 'important study, which will provide the economic key to the re-establishment and practical management of the South Island rain forests'. ${ }^{22}$ Based on the data provided by Foweraker, Ellis concluded that regulated forests consisting of the valuable but fast-disappearing silver pine (Manoao colensoi) with its light-resisting qualities potentially could be established in Westland instead of kahikatea (Dacrycarpus dacrydioides) and rimu (Dacrydium cupressinum). ${ }^{23}$ Apart from discovering which indigenous trees were best suited for regulation, ecological discoveries were made as well. For example, further research by Foweraker suggested that silver pine was a succession forest species to rimu, as the latter was dying out in dense areas of silver pines. ${ }^{24}$ However, conducting silvicultural research was far from an easy task. Apart from writing about the success of the studies, Ellis also recounted some of the hardships the investigators experienced. In one report, Ellis described one struggle reported by McGregor: 'In carrying out the research one of the greatest difficulties arises from the complete lack of reasonably trained assistance in the field'. ${ }^{25}$ Ellis also wrote about how Foweraker urged the need for a system of fire control, and described the devastation fires caused. Quoting from Foweraker's

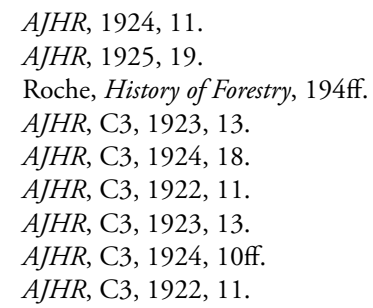


report, Ellis wrote how fires turned 'the original forest-floor, the seed-bed par excellence of the taxads' into 'a thick matted turf of exotic weeds, native sedges and rushes', which presented a difficult problem for the afforestation of the affected area. ${ }^{26}$ In addition to providing information about the progress of the investigations, Ellis wrote recurrently about the economic gains studying the forest's modus operandithat is, regeneration, growth levels and life history-would generate. According to Ellis, meeting New Zealand's timber requirements could only be achieved by reproducing and rebuilding the great indigenous forests of Westland, Southland and the central North Island, which were also the areas studied by Foweraker and McGregor, and later also Cockayne. ${ }^{27}$ Through their research, Ellis aimed to acquire 'a sound knowledge of what our forest land can be made to grow most profitably'. ${ }^{28}$ Indeed, science would not only ensure the sustainable production of timber, thereby saving the dominion from a timber famine, but also generate a profit. For Ellis, research was the cornerstone of profitability; hence his emphasis on the need for research. In his report for 1922, Ellis elaborated on the goal of the investigations, the possibilities of profit and the production of timber:

The ultimate field of silvical, ecological and silvicultural research is the economic production of wood-tissue. The technique of wood production cannot be attempted on scientific lines until technical ecological knowledge is crystallized regarding the optimum habitat conditions for forest-trees, and until silvical or forest-botanical facts are observed, noted, and summarized into guiding principles upon which to base the art and science of silviculture. ${ }^{29}$

According to Ellis, ecological research was a part of the solution to ensure a sustainable supply of timber, as he expected ecological investigations would provide knowledge and forest-botanical research serve as the bedrock of forestry decisionmaking. Ecological knowledge generated 'by trained botanists' was not considered a peripheral branch of forestry, but rather seen as elemental, providing 'guiding principles' for the future work of the SFS. ${ }^{30}$ A good example of Ellis' much-valued summaries and guiding principles is how he describes McGregor's research as work of 'immense value' after McGregor presented what Ellis considered to be 'certain practical conclusions of general nature', as mentioned earlier. Ellis was far from alone in considering ecology essential. Throughout the Western world during the early decades of the twentieth century ecology, emerged as one of the sciences. ${ }^{31}$ In New Zealand, ecological science had featured in state investigations since the first since the first decade of the twentieth century, due in large part to Cockayne, who derived many of his ideas from world-leading German ecologists, with whom he regularly

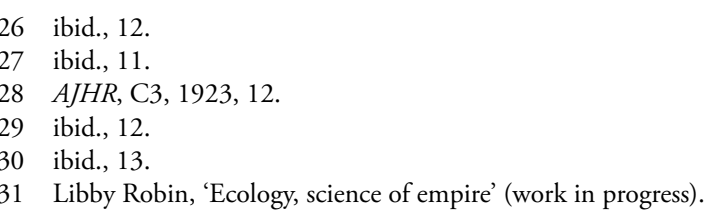


corresponded. ${ }^{32}$ Cockayne's early exchanges would not only give him a head start in the field of ecology in the dominion, they also resulted in the ideas of ecology being introduced much earlier in New Zealand than in neighbouring Australia. ${ }^{33}$ In New Zealand, scientists would also use ecology for two separate reasons, to argue for the conservation of certain areas and to examine the economic potential of native resources, such as flax, tussock and beech forests. ${ }^{34}$ At the beginning of the $1920 \mathrm{~s}$, ecology was an established form of botanical work in New Zealand. Environmental historian Paul Star notes that between 1923 and 1925, approximately 150 scientific researchers worked in the dominion, primarily at universities or for government departments, such as the SFS. ${ }^{35}$ The research undertaken by these scientists 'concerned the economic potential of the biota' and how it could be amplified in order to develop the dominion. ${ }^{36}$ However, the prominence of ecology in New Zealand forestry would soon fade away. ${ }^{37}$ At the same time as ecology's influence reached its peak, around 1925, Foweraker and Cockayne completed and presented their respective reports to Ellis regarding the prospects of using indigenous forests as timber supply. Though the reports provided substantial knowledge about indigenous forests' modus operandi, they had little impact on the work of the SFS, despite Ellis previously having underlined the importance of 'forest-botanical facts'. The reason for their limited influence was, ironically, Ellis himself. He had decided to abandon sustained-yield management in favour of exotic afforestation. Though Ellis initially considered indigenous forestry 'the central concern of the State Forest Service', Roche argues there were several reasons why Ellis changed his mind regarding the possibility of a forestry based on sustained-yield management in New Zealand.

First, recently published inventory reports by the SFS had indicated that timber demand would exceed supply by the 1960s. Second, the availability of more Crown land, previously contested and claimed by farmers, provided Ellis with the land he needed. A third factor contributing to Ellis having favoured exotic afforestation included the new market for softwoods. ${ }^{38}$ With exotic state plantations rather than the indigenous forests set to become the new primary provider of timber, Ellis aimed to increase their size from 63,000 to 300,000 acres within five years. Expanding the plantations, he calculated, would yield 450 million board feet of timber by 1965 .

\footnotetext{
32 James Braund, 'Leonard Cockayne's surveys of New Zealand's offshore islands, 1901-1908', New Zealand Geographer 72, no. 3 (December 2016): 173-5, doi.org/10.1111/nzg.12133; Paul Star, 'Ecology: A Science of Nation? The Utilization of Plant Ecology in New Zealand, 1896-1930', Historical Records of Australian Science 17, no. 2 (November 2007): 198.

33 Beattie, Empire and Environmental Anxiety, 147.

34 Star, 'Ecology', 198ff.

35 ibid., 199ff.

36 ibid., 200.

37 Ecology would remain a significant science in agriculture, especially through Leonard Cockayne's son Alfred and Bruce Levy.

38 Roche, '(Re)Interpreting Exotic Plantation Forestry in New Zealand', 162 and 165; Mike Roche, 'Latter day "Imperial Careering”: L. M. Ellis-A Canadian forester in Australia and New Zealand, 1920-1941', ENNZ: Environment and Nature in New Zealand 4, no. 1 (December 2009): 63.
} 
At the same time, Ellis expected the indigenous forests, no longer the main source for timber, would yield only a ninth as much as state plantations. In fact, Ellis even anticipated local bodies, proprietaries and private plantations altogether would yield more timber than the indigenous forests. ${ }^{39}$ With exotic plantations as the main source for timber, the need for 'guiding principles' derived from 'forest-botanical facts' declined, since ecological research studied indigenous vegetation in all its aspects, not the 'simplified agroecosystems' of state plantations solely consisting of Pinus radiata. ${ }^{40}$ Though the shift resulted in a blow for the prominent position ecology had enjoyed within forestry, it did not mean it was disregarded, nor that its scientific value disappeared. The reports were still seen as respected scientific works, the most prominent case being Cockayne's study of the beech forest. Upon the completion of his investigation, Ellis noted how in Cockayne's research ' $[\mathrm{m}]$ any details came to light concerning regeneration and the rate of growth of the different species [Nothofagus], knowledge which is fundamental in regard to any methods of silviculture'. ${ }^{41}$ Furthermore, the SFS hoped his report, titled A Monograph on the Beech Forests of New Zealand, would, with its numerous illustrations, 'bring clearly to the public a knowledge of the extreme value of the beech forests'. ${ }^{42}$ Meanwhile, Foweraker's report was not expected by the SFS to bring the public any knowledge similar to Cockayne's. Foweraker, on the other hand, wished to share his results to a wider audience and published them in Ngahere, a journal newly founded by the Forestry Club of the Canterbury College School of Forestry. ${ }^{43}$ The aim of Ngahere was 'to discuss forestry in all its aspects' with the public, in the hope of thereby spreading knowledge of forestry research to a wider audience. ${ }^{44}$ Moreover, both Foweraker and Cockayne presented their findings in the form of lectures. ${ }^{45}$ Even McGregor would, while working for the SFS, advertise lectures on forestry in the newspaper. ${ }^{46}$ Roche argues that the investigations of Cockayne and the others resulted in a better understanding of the New Zealand environment. However, because the results were presented in scientific language, it became difficult to communicate the findings, and their consequences, to both the official and popular sectors. ${ }^{47}$ As a result, '[p]olitical decision makers ... had to accept the recommendations of the forest scientists without being able to critically evaluate them'. ${ }^{48}$ Though science

39 AJHR, C3, 1925, 7.

40 Star, 'Ecology', 200.

41 AJHR, C3, 1925, 18.

42 ibid., 18; Leonard Cockayne, A Monograph on the Beech Forests of New Zealand (Wellington: Government Printer, 1926-28).

43 Charles E. Foweraker, 'The Rain Forest of Westland', Te Kura Ngahere, 1 (1925): 7-9; Charles E. Foweraker, 'The Podocarp Rain Forests of Westland. No. 2. Khaikatea and Totara Forests and Their Relationship to Silting', Te Kura Ngahere 2, No. 4 (1929): 6-12.

44 The editor (probably F. E. Hutchinson), Te Kura Ngahere 1 (1925): 1.

45 'Forestry. Conference of executive officers. Important matters discussed', The Press (Christchurch), 6 May $1924,8$.

46 'Auckland University College. Lectures on forestry', New Zealand Herald (Auckland), 11 June 1921, 16.

47 Roche, History of Forestry, 198.

48 Roche, History of Forestry, 198. 
became more professionalised, and an understanding of the results now required a training in scientific language, it remained an ambition of both the SFS and the individual researchers to inform a wider audience of their recent findings. Indeed, wanting to awaken public interest through scientific publications and lectures was not uncommon among researchers in New Zealand at the time. As scholars have shown, scientists aimed to educate the public in a range of topics, from Darwinism in the 1870 s to nutrition and health issues during the 1920 s. ${ }^{49}$ Even environmental matters, in particular those related to meteorology, were discussed among scientists and politicians, and in the press from the 1860 s onwards.$^{50}$ According to the editor of Ngahere, reaching and informing a wider audience about forestry was of significance since forestry was in the minds of many people ... merely the growing of trees and the cutting of them down', though it in fact, just like medicine and other sciences, it occupied 'a place of world-wide importance'. ${ }^{51}$ The ambitions of both the SFS and the Forestry Club of the Canterbury College School of Forestry provide a good indication of how both state and scientists hoped and tried to shape public opinion through the publication of scientific reports. While the shift to a forestry practice reliant on exotic afforestation rather than sustained-yield management did affect the position of 'ecological and silvical research', the SFS continued to conduct ecological research, although on a smaller scale. Of Foweraker, McGregor and Cockayne, only the latter would continue to write reports for the SFS. Cockayne, however, would not research ecological aspects of the indigenous forests alone. Corresponding with botanists all over the world, he would on occasion invite them to visit New Zealand to conduct studies. One of those botanists was Du Rietz from Uppsala University, who during his visit to New Zealand would not only study lichens for his own research but also on behalf of the SFS.

49 For Darwinism, see John Stenhouse, 'The Darwinian Debates in Dunedin', in Aspects of Darwin: A New Zealand Celebration, ed. David Galloway and John Timmins (Dunedin: Friends of the Knox College Library, 2010), 110-16. For nutrition and public health, see Philippa Mein Smith, A Concise History of New Zealand (Cambridge: Cambridge University Press, 2011), 140-4, doi.org/10.1017/CBO9781139196574.

50 James Beattie, 'Climate Change, Forest Conservation and Science: A Case Study of New Zealand, 1860s-1920', History of Meteorology 5 (2009): 1-18; James Beattie, Emily O'Gorman and Matt Henry, eds, Climate, Science, and Colonization: Histories from Australia and New Zealand (New York: Palgrave Macmillan, 2014), doi.org/10.1017/ CBO9781139196574.

51 The editor (probably F. E. Hutchinson), Te Kura Ngahere, 1. 


\section{A Swedish lichenologist and the deforestation problem of New Zealand}

On 29 July 1926, the Swedish Australasian Botanical Expedition set sail from Sweden, beginning its long journey to the other side of the world. ${ }^{52}$ The aim of the expedition was to conduct studies comparing vegetation in the countries it visited. It set the foundation for a critical revision regarding the general principles of the scientific classification and treatment of fundamental units in phytosociology in New Zealand, Australia and Java. ${ }^{53}$ Though this was an ambitious aim, the expedition consisted of only two people. The first member was G. Einar Du Rietz, a lecturer in botany who specialised in lichen and, at the time of the departure, a curator at the herbarium of Uppsala University. The other member of the party was his wife Greta Sernander-Du Rietz, also a lichenologist. ${ }^{54}$ The couple would spend seven months in New Zealand, travelling through the dominion in search of lichen, from Auckland in the north to the Auckland Islands in the south. During their time in New Zealand, Du Rietz specifically studied lichens in the mountains to test a hypothesis he had suggested in Uppsala-namely, that a thorough examination of mountain lichens 'would lead to a multiplication of the Arctic element in the New Zealand flora'. ${ }^{55}$ Apart from investigating this hypothesis, Du Rietz also, at the request of the SFS, studied the possibility of using lichens as indicators to determine the relative humidity of various types of forest. ${ }^{56}$ In November 1926, the Evening Post informed its readers that a 'noted visitor' had arrived in Wellington. ${ }^{57}$ The visitor was none other than Du Rietz, who the newspaper explained was a Swedish botanist and lecturer in botany at Uppsala, 'which, as far as botany is concerned, is probably the most famous university in the world', as it once had been 'the workshop of the great Linnaeus'. ${ }^{8}$ However, it was not his connection to Linnaeus which made him a 'noted visitor', though it certainly added a certain kind of historical prestige. Rather

52 Gustaf Einar Du Rietz, Den svenska botaniska Australasia-expeditionen 1926-1927: Preliminary report (in Swedish) of the results of the Swedish botanical expedition to New Zealand and Australia (and also to North America and Java) in 1926-7 (Corrected offprint from Ymer 48 (1928): 421-9) (Uppsala: Dahlia Books, 1974), 421.

53 Du Rietz, Den svenska botaniska Australasia-expeditionen, 1926-1927, 421.

54 Though an excellent lichenologist in her own right, despite lacking any formal training or university examinations and instead having received her education from her father, Rutger Sernander, Professor of Botany at Uppsala University, Greta Sernander-Du Rietz's work was overshadowed by her husband's. During their stay in New Zealand she played an important role, collecting and preserving the specimens her husband collected, but she did not write anything herself on lichenology until later in life. As a result, this article will primarily focus on Gustaf Einar Du Rietz. For further reading about Greta Sernander-Du Rietz, see Per M. Jørgensen and Louise Lindblom, 'Greta Sernander-DuRietz. Sveriges första kvinnliga lavforskre', Svensk botanisk tidskrift 100, no. 4 (2006): 256-60. 55 Gustaf Einar Du Rietz, 'The Discovery of an Arctic Element in the Lichen-Flora of New Zealand and its Plantgeographical consequences', in Report of the Hobart meeting, 1928, 628ff.

56 Du Rietz, Den svenska botaniska Australasia-expeditionen 1926-1927, 428.

57 'The Study of Lichens: Swedish botanist's visit. Extensive Tour of New Zealand', Evening Post (Wellington), 25 November 1926. This article is a clear example of how Greta Sernander-Du Rietz was overshadowed by her husband and only referred to as 'his wife'.

58 'The Study of Lichens: Swedish botanist's visit. Extensive Tour of New Zealand', Evening Post, 25 November 1926. 
it was due to his being 'virtually the founder of the Swedish school of ecology', which the newspaper explained was 'the study of plants as they grow naturally in the open air. He is also probably the foremost expert regarding lichens'.$^{59}$ It was the latter, his expertise in lichens, that had brought Du Rietz to New Zealand. One of his many botanical interests concerned the 'phytogeographical problems posed by the bipolar distribution of various plant groups', which had led to a growing correspondence between him and Cockayne, and later also New Zealand botanist H. H. Allan, who sent Du Rietz several examples of lichens in $1925 .^{60}$ Thus, Du Rietz was far from unfamiliar with New Zealand lichens when he arrived the following year. Though the study of lichens from a phytogeographical perspective in the dominion was the aim of the expedition, the Evening Post concentrated on another, potential, aspect of his coming study, namely its economic dimensions:

$[\mathrm{H}]$ is work [on lichens] will probably be of great economic importance for New Zealand forestry. In his connection, it is the opinion of Dr. L. Cockayne ... that lichens are exact indications of climate, of sun and shade, etc. Thus it may be from the study of these curious plants, generally neglected, that an exact knowledge will come of what forest trees can be grown in various parts of New Zealand forests, in order to fill up the gaps by sawmilling, etc. ${ }^{61}$

While the prominent lichenologist and historian David Galloway has covered the lichenological aspects of the expedition's journey in New Zealand and the scientific interest as well as the scientific networks it generated, he overlooked how Du Rietz's work on lichens related to the deforestation problem. ${ }^{62}$ As mentioned above, during the seven months the expedition was to study lichens, Du Rietz was also asked to conduct on behalf of the SFS a special survey on the possibility of using lichen as an indicator to determine the relative humidity of various types of forest. ${ }^{63}$ However, his research for the SFS received little attention in the annual reports compared to previous studies by McGregor, Foweraker and Cockayne. In fact, they contain nothing about Du Rietz having been commissioned to write a report. Instead, Ellis states in the report only how the service was pleased to have been of assistance and how ' $[\mathrm{h}]$ is observations will shed light on the origin and history of the indigenous species, and show how these are connected with those of other countries'. ${ }^{64}$ Though Du Rietz received little attention in the annual reports, he did get a chance to

\footnotetext{
59 ibid.

60 David Galloway, 'The Swedish connection in New Zealand lichenology, 1769-2004', Symbolae Botanicae Upsaliensis 34, no. 1 (2004): 66ff; David Galloway, 'H. H. Allan's early collection of New Zealand lichens', New Zealand Journal of Botany 14, no. 3 (1976): $226 \mathrm{ff}$.

61 'The Study of Lichens'.

62 See, for example, David J. Galloway, 'Austral lichenology: 1690-2008', New Zealand Journal of Botany 46, no. 4 (2008): 447, 461-3 and 471, doi.org/10.1080/00288250809509781; Galloway, 'The Swedish connection in New Zealand lichenology'; Galloway, 'H. H. Allan's early collection of New Zealand lichens'.

63 Du Rietz, Den svenska botaniska Australasia-expeditionen 1926-1927, 428.

$64 A J H R, \mathrm{C} 3,1927,20$.
} 
discuss his initial findings in the in-house journal of the SFS, Te Karere o Tane. In his article, Du Rietz shared his general thoughts on the vegetation of New Zealand, in particular the tree line and, lastly, the usefulness of lichens as indicators of moisture.

Regarding vegetation, Du Rietz underlined how he was struck by the fact that despite 'the very great variety in climatic conditions, only one of the main forest types of the world is represented in the country, namely an evergreen forest of more or less pronounced rain-forest character' ${ }^{65}$ By comparing the vegetation in New Zealand with the northern hemisphere and South America, Du Rietz argued that 'the widespread supposition that every type of climate has one corresponding general type of vegetation' did not explain the structure of the vegetation of New Zealand ${ }^{66}$ Instead, he suggested that the general type of vegetation seems to be determined to a very large extent by the plant material available' ${ }^{67}$ Since the indigenous forest consisted of an old tropical forest-climax largely dominated by podocarps' originating in New Guinea, a forest 'nearly completely lacking elements able to produce deciduous, or ... more frost-tolerating trees', Du Rietz believed that the 'real limite [sic] for possible forest growth' could be much higher than the current tree line. ${ }^{68} \mathrm{He}$ illustrated his point by using the dryer parts of the South Island as an example, writing:

It is not the climate which is responsible for the fact that the dryer parts of the South Island have got no deciduous beech-forest like corresponding parts of South America, or no coniferous forests like the corresponding parts of the northern hemisphere, but it is simply the inability of the New Zealand Nothofagus-population to produce deciduous species, and the lack of indigenous pines. Recent afforestation seems to give a good proof of the quite good 'forest-climate' of the tussock country. ${ }^{69}$

Drawing upon both his phytogeographical knowledge and familiarity with the forests in the northern hemisphere, Du Rietz concluded that afforesting New Zealand through an elevation of the tree line was possible, if done with exotic species. Additionally, he wrote about the possibility of growing exotic trees among the indigenous rainforests, though he was unsure which exotic species would be useful. Du Rietz suggested that the 'lichen vegetation ... seems to follow the changes in humidity in a very sensible way', in particular big lichens such as Pseudocyphellaria coronata, and could be used to determine a 'certain amount of constant moisture'. ${ }^{70}$ However, regarding its usefulness for forestry, Du Rietz underlined that further research was required. ${ }^{71}$ In addition to Te Karere $o$ Tane, he also received coverage in the newspapers, indicating the importance of botanical research to the general public.

65 Gustaf Einar Du Rietz, 'Comparative ecology of N.Z. vegetation in general', Te Karere O Tane 6, no. 2 (1927): 3.

66 ibid., 3.

67 ibid., 3.

68 ibid., 4.

69 ibid., 5.

70 ibid., 6.

71 ibid., 6. 
The articles covering Du Rietz primarily focused on two aspects, his collecting of lichens, and where he collected them, together with his praise of the New Zealand scenery and how New Zealand was 'one of the most interesting countries for a botanist' to visit. ${ }^{72}$ However, on a few occasions the newspapers also wrote about his connection to the SFS and the potential economic impact of his research. For example, in an interview Du Rietz gave to The Press after returning to Christchurch, having collected lichens at Canterbury College's biological research station at Cass with his wife, Cockayne, Allan and Foweraker, Du Rietz was reported saying:

Many years ago lichens were used during times of economic stress, in making bread, and they have also played a part in the distilling of whisky ... They have no actual economic value, [a] part from what I have mentioned, but are invaluable as indicators of suitable climates for different forest trees. ${ }^{73}$

Though Du Rietz argued that lichens had no economic value, he suggested that studying them could generate scientific knowledge, which in turn could be amplified to issues of economic interest. His hope of using science to solve practical issues - in this case verifying suitable climates for different trees - was far from unique; rather it was, as previous research shows, a key defining characteristic in the colonies. ${ }^{74}$

Shortly before departing New Zealand, Du Rietz gave one last interview, dedicated entirely to the subject of forestry and afforestation. In it, he praised the efforts made by the SFS and supported the use of exotic trees to meet the demand for timber instead of using indigenous forest, due to the latter's slow growth. Moreover, and perhaps more importantly, he thought the policy would ensure 'the keeping of the indigenous forest ... for scientific and scenic purposes'. ${ }^{75}$ Apart from commending the new policy of the SFS and expressing confidence it would save the indigenous forests, Du Rietz also talked about which trees could be planted and where in the future, if the SFS needed to expand their state plantations beyond the lowlands, stating:

I suppose the vast forest-clad lowlands will give a working field for forest-planting quite enough for many years. But if it should prove desirable in the future to extend the forest-area over the originally unforested dry tussock country or above the present alpine forest-line, I am sure the South American deciduous beeches should be well worth trying. The north-west European mountain-birch would probably also grow excellently in the high country, but would be of little economic value. ${ }^{76}$

72 See, for example, 'Distinguished Botanist: Study in Dominion', New Zealand Herald, 11 December 1926; 'Rich in Lichens: Search by Scientist', Auckland Star, 15 January 1927; 'New Zealand Flora: Swedish Botanist's Praise. Important Find of Lichens', New Zealand Herald, 31 January 1927; 'A Botanist's Paradise: Our Flora and Scenery Praised. Distinguished Visitor's Impressions. Investigations in Southern Islands', Otago Daily Times (Dunedin), 9 April 1927; 'Solitary Isles: The Dominion's Outposts. Birds and Strange Plants. A Museum Officers Notes', Evening Post, 16 April 1927. Quotation from Otago Daily Times, 9 April 1927.

73 'General News', The Press, 26 January 1927.

74 See, for example, Brooking and Star, 'Remaking the Grasslands: the 1920s and 1930s'.

75 'Correct Policy: Swedish expert's views', Evening Post, 30 June 1927.

76 ibid. 
Du Rietz's last interview with the New Zealand press shares many similarities with his article in Te Karere o Tane, but also provides new insight regarding his thoughts on the work of the SFS and how the new forest policy enabled the conservation of the indigenous forests for scientific, and scenic, reasons. Moreover, he also developed his idea regarding elevating the tree line by discussing which trees would be useful. Paradoxically, while Du Rietz was happy with the decision to save indigenous forests, he had no quarrel with altering non-forest terrain; on the contrary, it was something he advocated even though he was uncertain it would be economically profitable.

During their time in New Zealand, the expedition managed to collect almost 3,000 specimens of lichens. ${ }^{77}$ Unfortunately, once Du Rietz returned to Sweden he found little time to study the samples due to protracted negotiations regarding who was to hold the chair of Ecological Botany at Uppsala and thereby succeed Rutger Sernander, his father-in-law. In addition, Du Rietz began to develop new research interests, leaving even less time to study the New Zealand lichens. ${ }^{78} \mathrm{He}$ did, however, manage on his return voyage to Sweden to write a report for the Australasian Association for the Advancement of Science concerning the expedition's scientific findings and their consequences. In his report, though, Du Rietz never mentioned the possibility of using lichens to determine the humidity of a forest, nor did he discuss lichens in reference to afforestation, or deforestation for that matter. Rather he focused on issues surrounding plant geography and the Arctic element in the lichen flora of New Zealand, which had been the primary objective of the expedition. ${ }^{79}$

Despite the lack of a report by Du Rietz on how lichens could be used in matters relevant to forestry, his few months' employment with the SFS is still worth highlighting as it shows how the SFS aimed to investigate a multitude of ecological indicators and elements, in this case lichens, to gain vital information for the purposes of forestry. The importance of studying various ecological parameters can also be observed in how Ellis emphasised the need for botanical facts. Moreover, Du Rietz can be placed in two kinds of contexts, the first being lichenology, explored by Galloway, where an emphasis is put on the scientific results of the expedition and the lichenology network between Swedish and New Zealand scientists it generated.

The second, a much larger context in which the expedition can be placed, is the one of non-British influence on environmental issues in New Zealand. The fear of a wood shortage due to deforestation was but one of many environmental anxieties in New Zealand during the late nineteenth and early twentieth centuries. Environmental historian James Beattie shows that these anxieties in turn tied

\footnotetext{
77 Galloway, 'The Swedish connection in New Zealand lichenology', 69.

78 ibid., 70ff. Du Rietz would, however, still be in contact with the botanists he met in New Zealand, Allan in particular, who in 1936 became head of the Botany Section at the DSIR. On Du Rietz's initiative, Allan later became a member of the Swedish Phytogeographical Society, and, in 1957, shortly before his death, he was awarded an honorary MA as well as a PhD from Uppsala University for his work on lichen.

79 Gustaf Einar Du Rietz, 'The Discovery of an Arctic Element in the Lichen-Flora of New Zealand', 628-35.
} 
New Zealand together with 'different parts of the British Empire and beyond'. ${ }^{80}$ Apart from a strong exchange of knowledge with India and Australia on a range of environmental issues, Beattie also highlights the impact of German forestry ideals, as well as French solutions to sand erosion in New Zealand. ${ }^{81}$ Though Du Rietz did not have the same lasting impact as his German predecessors on forest conservation, contemporary leading scientists, such as Cockayne, who was influenced by German scientists, had high hopes that Du Rietz's trip would result in much-needed knowledge for the dominion and its forests. Furthermore, this emphasises the important role foreign expertise played for domestic scientists, who, like Cockayne, used the work of visiting experts in support of their agendas.

\section{Summary}

As Ellis and the SFS hoped to prevent a timber famine and at the same time conduct forestry suitable to the conditions of New Zealand, they turned to the sciences of botany and ecology for help. Ellis considered the two sciences necessary, arguing that they could provide knowledge regarding the modus operandi of nature and set guiding principles for a forestry in New Zealand that was both profitable and sustainable. However, since the SFS lacked sufficient personnel, Ellis had to hire expertise from outside the service in order to carry out the ecological research. However, rather than employing foresters, Ellis hired botanists. Hiring botanists may at first seem surprising, but, as Star shows, ecology was at the beginning of the 1920s an established science among botanists in New Zealand, who surveyed the economic possibility of the native resources of the dominion. At the same time, Ellis wanted to conduct a forestry model based on sustained-yield management of indigenous forests. It was a perfect match.

Despite ecology's importance to forestry, research has tended to study the role of ecology in New Zealand during the 1920s and Ellis' argument for sustained-yield management more or less separately. Studying the utilisation of botanists by the SFS not only highlights the relationship between science and the state but also brings attention to the role of the New Zealand state as a producer of science, since employment by the SFS provided the botanists with the possibility of conducting large-scale and long-term ecological surveys. In addition, the investigators referred to their research in their attempts to shape public opinion on forestry matters.

80 Beattie, Empire and Environmental Anxiety, 38.

81 ibid., 146-8, 193-6. 
In 1925, the need for botanical guidelines declined as Ellis began to advocate exotic afforestation rather than sustained-yield management of indigenous forests. Nonetheless, ecological research was still carried out by the SFS. More importantly, the service was quick to take advantage of foreign expertise, approaching Du Rietz during his visit to New Zealand, asking if he could compile a report on the usefulness of lichens in forestry. Reports conducted by non-British forestry experts, as Beattie shows, were far from atypical, as shown by the impact of German scientists from the mid-nineteenth to the early twentieth century. Du Rietz never completed his survey for the SFS due to shifting research interests and academic circumstances once back in Sweden. His short-term employment at the SFS, together with the ongoing reporting of his collection of lichens by newspapers, is suggestive of a wide role for foreign expertise in New Zealand in the 1920s, especially in the field of ecology, further examples of which could be provided by additional research.

\section{Acknowledgements}

The author would like to thank the journal's editor, Associate Professor James Beattie, and the three anonymous reviewers for their insightful and helpful comments. A special thanks to Rolf E. Du Rietz for providing me with source material, making this article possible. 
This text is taken from International Review of Environmental History, Volume 5, Issue 1, 2019, edited by James Beattie, published 2019 by ANU Press, The Australian National University, Canberra, Australia. 